\title{
Cancer, Natural Products and Nanodrug Delivery Systems
}

\author{
Yong Sze Ong ${ }^{1,2 *}$, Loh Teng-Hern Tan ${ }^{3}$ \\ ${ }^{1}$ Biofunctional Molecule Exploratory Research Group (BMEX), School of Pharmacy, Monash University Malaysia, 47500 \\ Bandar Sunway, Selangor Darul Ehsan, Malaysia \\ ${ }^{2}$ Health and Well-Being Cluster, Global Asia in the 21st Century (GA21) Platform, Monash University Malaysia, 47500 \\ Bandar Sunway, Selangor Darul Ehsan, Malaysia \\ ${ }^{3}$ Novel Bacteria and Drug Discovery Research Group (NBDD), Microbiome and Bioresource Research Strength, Jeffrey \\ Cheah School of Medicine and Health Sciences, Monash University Malaysia, 47500 Bandar Sunway, Selangor Darul Ehsan, \\ Malaysia
}

\begin{abstract}
As an offshoot of nanotechnology, nanomedicine has made great impact in the field of pharmaceutical and biomedical sciences by achieving breakthroughs in therapeutics and diagnostics of diseases in living organisms. One of the promising breakthroughs is the application of natural product-based nanoformulations for the treatment of various human diseases, such as cancer. Principally, the nanoparticle-based drug delivery system (NDDS) aims to overcome the limitations of conventional drug delivery system. NDDS improves the in vivo pharmacological and therapeutic properties of the poorly soluble drugs by dissolving, encapsulating, absorbing and/or attaching the drugs with the matrices of the nanoparticles. The nanoparticles that act as drug reservoirs also aim to control the drug release, enhance the drug uptake by targeted delivery and protect the drug against enzymatic degradation. This review presents a summary of the integration of nanotechnology and phytotherapy to achieve an improved pharmacological response and better clinical outcome in patients undergoing chemotherapy.
\end{abstract}

Keywords: nanomedicine; chemotherapy; natural product; drug delivery; nanoparticles

Received: $27^{\text {th }}$ April 2020

Accepted: $28^{\text {th }}$ May 2020

Published Online: $5^{\text {th }}$ June 2020

*Correspondence: Yong Sze Ong, School of Pharmacy, Monash University Malaysia, 47500 Bandar Sunway, Selangor Darul Ehsan, Malaysia. Ong.YongSze@monash.edu

Citation: Ong YZ, and Tan LT-H. Cancer, Natural Products and Nanodrug Delivery Systems. Prog Microbes Mol Biol 2020; 3(1): a0000089. https://doi.org/10.3687/pmmb.a00000089

\section{INTRODUCTION}

Cancer remains as one of the leading causes of mortality globally, irrespective of the advent of current available forms of cancer treatment. In 2018, cancer has accounted for an estimated of 9.6 million deaths worldwide ${ }^{[1]}$. The current therapeutic modalities, such as chemotherapy and radiotherapy, are associated with limitations, including damaging to proliferating healthy tissues, systemic toxicity, chronic side effects and emergence of drug resistance within tumor cells. Hence, there is always a continuous need of more effective strategies for the treatment of different human malignancies.

Throughout the history of mankind, natural products have played a pivotal role in the treatment of various diseases. Natural products derived from plants, animals and microorganisms represent the prolific bioresources for pharmacologically active compounds, including as chemotherapeutic agents ${ }^{[2-12]}$. These natural products have been extensively studied for the prevention and treatment of cancer, such as paclitaxel, vincristine, camptothecin and resveratrol ${ }^{[13]}$. Although they have been demonstrated to possess strong therapeutic value, the clinical application of these promising natural product derived compounds is severely hampered by their poor solubility and bioavailability ${ }^{[14]}$.

As an offshoot of nanotechnology, nanomedicine has made great impact in the field of pharmaceutical and biomedical sciences by achieving breakthroughs in therapeutics and diagnostics of diseases in living organisms. One of the promising breakthroughs is the use of nanoparticles in the development of drug delivery system to improve the treatment of various diseases, including cancer ${ }^{[15]}$. Principally, the nanoparticle-based drug delivery system (NDDS) aims to improve the in vivo pharmacological and therapeutic properties of the poorly soluble drugs by dissolving, encapsulating, absorbing and/or attaching the drugs with the matrices of the nanoparticles. The nanoparticles that act as drug reservoirs also aim to control the drug release, enhance the drug uptake by targeted delivery and protect the drug against enzymatic degradation. In 2005, the National Cancer Institute (NCI) has launched the Alliance for Nanotechnology in Cancer due to the emerging of nanomedicine and their potential applications in 
cancer research ${ }^{[16]}$. Under this approach, nanoparticlebased drug delivery system has been approved as one of the effective strategies to overcome the limitations of conventional chemotherapy with numerous nanoparticlebased drugs and delivery system that are in clinical use. In this review, we aim to critically consolidate the advent of nanotechnology in the context of chemotherapeutic drug delivery. This review also presents the examples of the extensively studied natural product-derived compounds using nanotechnology, including doxorubicin, paclitaxel and vincristine.

\section{BRIEF OVERVIEW OF CANCER}

Cancer is a collection of genetic diseases characterized by the uncontrolled cell growth as a result of dysregulated processes of cell division and cell death. Cancer cells are abnormal cells which lose their ability to undergo apoptosis (the programmed cell death) and uncontrollably proliferate, subsequently leading to formation of malignant tumour that invades to adjacent tissues ${ }^{[16]}$. The formation of tumour (tumourigenesis) involves a complex multistep process (tumour initiation, tumour promotion and tumour progression) that transforms a normal cell into a malignant one due to DNA mutation. In 2011, "the hallmarks of cancer" have been revised, explaining the defect mechanisms of malignant cells that deviate from normal cellular functions (Figure 1) ${ }^{[17]}$.

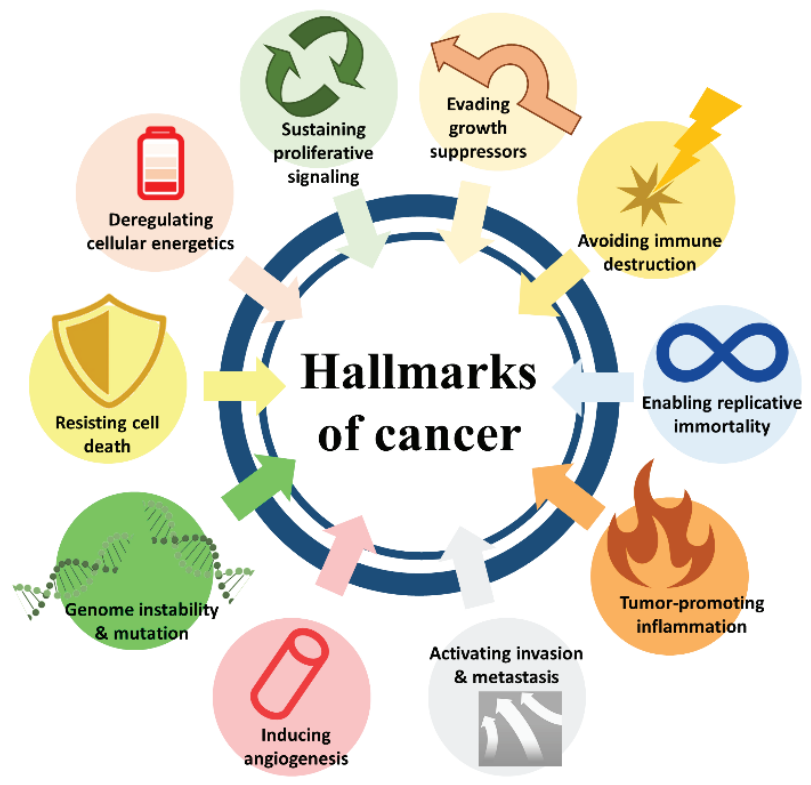

Figure 1. The ten hallmarks of cancer ${ }^{[17]}$.

These cancer hallmarks are the common traits of tumour cells with their capabilities to alternate the cell growth (sustaining proliferative signalling and evading growth suppressors), to evade apoptosis and cell cycle (resisting cell death and enabling replicative immortality), to modify cellular metabolism (deregulating cellular energetic), to destruct immunological function, to induce angiogenesis, invasion and metastasis. Additionally, the genomic instability ${ }^{[18-22]}$ and inflammation by immune cells facilitate the tumourigenesis ${ }^{[17]}$.

\section{APOPTOSIS AND CANCER}

One of the prominent hallmarks of cancer is the ability to resist cell death ${ }^{[17]}$. Cell death is a fundamental programme that happens for two purposes; under defence mechanism when the cells received stressful stimuli or under homeostasis mechanism to remove damaged or aged cells for maintaining cell population ${ }^{[23,24]}$. The cell death could occur by either necrosis or apoptosis, depending on the response of the cell to the stimuli ${ }^{[25]}$.

Necrosis is an "accident" or premature cell death that occurs when the cells encountered irreversible stimuli such as infectious agents, hypoxia, heat and radiation ${ }^{[26]}$. The necrotic cells experience rupture in the plasma membrane and organelles due to the swelling of cytoplasm. The cytoplasmic contents are then released to the extracellular space and triggered an inflammatory response ${ }^{[27]}$.

In contrast, apoptosis is a "suicide" or programmed cell death that occurs under some physiological conditions to maintain homeostasis ${ }^{[28]}$. Aged and damaged cells that may interfere with body function are removed from the system $^{[29]}$. Apoptotic cells experience the blebbing of plasma membrane, cell shrinkage, DNA fragmentation and activation of specific proteases (caspases). As different from necrosis, the apoptotic process does not trigger the inflammatory response as the apoptotic cell externalises the phosphatidylserine at the outer leaflet of plasma membrane to be recognised and engulfed by .phagocytes ${ }^{[30,31]}$.

Tumour initiation (hyperproliferation of cell) happens when apoptosis fails to eliminate the genetic mutated cells ${ }^{[32]}$ Ryia-Illani Mohd. These mutated cells proliferate uncontrollably by evading apoptosis via several mechanisms. One of the common mechanisms is the loss of function of TP53 tumour suppressor gene ${ }^{[17]}$. TP53 tumour suppressor gene encodes the $\mathrm{p} 53$ protein which is responsible to transcript more than 125 genes coordinating the repairing of DNA, cell cycle and apoptosis. The mutation of TP53 gene has been identified as a common molecular characteristic in human cancer ${ }^{[33]}$. Therefore, TP53 has become a potential target in cancer treatment with the aim to restore the transcription function ${ }^{[34]}$.

Apoptosis is executed via two downstream signalling pathways: intrinsic and extrinsic pathways, depending on the source of the stimuli (Figure 2) ${ }^{[35]}$. The intrinsic pathway receives the intracellular death signals from non-receptor-mediated stimuli and initiates the events in mitochondria ${ }^{[24]}$. The up-regulation of pro-apoptotic proteins (Bax, Bad and Bim) or/and down-regulation of anti-apoptotic proteins (Bcl-2, Bcl-xL and Bag) stimulate the release of cytochrome $\mathrm{c}$ from mitochondria, leading to the formation of apoptosome in the cytosol. The apoptosome then initiates a cascade of proteolysis with the effector caspases (caspase-3 and -7) that lead to the execution of apoptosis ${ }^{[36]}$.

On the other hand, extrinsic pathway receives extracellular death signals from transmembrane death receptors such as tumour necrosis factor (TNF) receptor and Fas receptors after binding with their homologous ligands (TNF- $\alpha$ and FasL). Activation of these death receptors results in the activation of Fas-associated death domain protein (FADD) and caspase- 8 that further initiates the effector caspases (caspase-3 and -7) and triggers apoptosis ${ }^{[37,38]}$. 


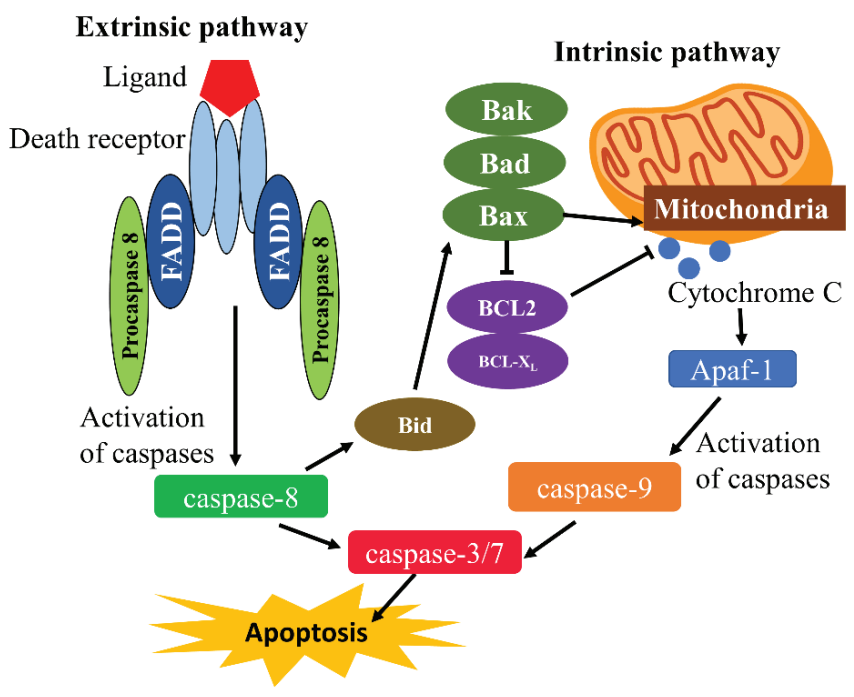

Figure 2. The intrinsic and extrinsic pathways of apoptosis ${ }^{[35]}$.

\section{Angiogenesis and Cancer}

Another hallmark of cancer is the induction of angiogenesis ${ }^{[17]}$. Angiogenesis is the formation of new blood capillaries from existing blood vessels ${ }^{[39]}$. Formation of new capillaries in the tumour enables the tumour cells to obtain nutrients and oxygen and to remove the metabolic waste and carbon dioxide. This has promoted the tumour growth and metastasis of tumour cells to other organs ${ }^{[17,40]}$. Vascular endothelial growth factor (VEGF) family members such as VEGF $\mathrm{A}$ and $\mathrm{B}$ proteins are the key components to induce angiogenesis. In response to hypoxia, the level of hypoxia inducible factor-1 $\alpha$ (HIF-1 $\alpha$ ) promotes the expression of these pro-angiogenic VEGFs in tumour ${ }^{[41]}$. The VEGFs then bind to their respective receptors on the endothelial cells in the extracellular matrix, causing the differentiation of endothelial cells to form new capillaries ${ }^{[42]}$. Therefore, VEGF has become the therapeutic target to control the tumour growth, angiogenesis and metastasis ${ }^{[41,43]}$.

\section{Metastasis and Cancer}

Activation of invasion and metastasis is one of the characteristics of malignant cancer ${ }^{[17]}$. Metastasis is defined as the spread or development of cancer in other distinct organs from the primary tumour through blood and/or lymphatic vessels ${ }^{[44]}$. It is always related to poor prognosis as it is the leading cause of cancer death ${ }^{[45]}$. For tumour cells to pass through the tissue barriers, they have to develop the ability to break through the extracellular matrix $(\mathrm{ECM})^{[46]}$. One of the proteolytic enzymes that are responsible to degrade
$\mathrm{ECM}$ is the matrix metalloproteinases (MMPs). ECM metalloprotease inducers (EMMPRIN) are produced on the membrane of the tumour cells to activate MMPs including the MMP-2 (72-kDa Gelatinase A) and MMP-9 (92-kDa Gelatinase $\mathrm{A})^{[47]}$.

\section{NATURAL PRODUCTS AS A SOURCE OF CHEMOTHERAPEUTIC AGENTS}

Natural products are defined as the compounds that are produced from nature such as plants, microorganisms and animals as a result of nutritional needs and evolution to adapt the environmental challenges ${ }^{[48-62]}$. Historically, plants have been extensively documented in traditional medical systems such as traditional Chinese medicine, Indian Ayurvedic system and Egyptian "Ebers Papyrus" to promote health and cure diseases ${ }^{[63]}$. Nowadays, plants have become an important source for discovery of bioactive compounds (phytochemicals) with promising therapeutic activities such as anti-cancer, anti-inflammatory and anti-bacterial effects $^{[13,64-75]}$.

Majority of the marketed chemotherapeutic agents were isolated and derived from medicinal plants due to the advantages of readily available and cost effective ${ }^{[76]}$. The well-known examples of plant-derived chemotherapeutic compounds are paclitaxel from Taxus brevifolia ${ }^{[77]}$, camptothecin from Camptotheca acuminata ${ }^{[78]}$, vinblastin and vincristine from Catharanthus roseus ${ }^{[79]}$. These phytochemicals can be further classified into alkaloids, flavonoids, taxanes, lignans, stilbenes and more ${ }^{[76]}$. Table 1 summarises some of the potential and clinically approved plant-derived chemotherapeutic compounds with their mechanisms of action.

Table 1. Potential and clinically approved plant-derived chemotherapeutic compounds with their mechanisms of action

\begin{tabular}{lll}
\hline Phytochemical & Plant name and part & Mechanism of action and type of cancer \\
\hline Camptothecin & Camptotheca acuminata & $\begin{array}{l}\text { DNA topoisomerase I inhibitor in glioblastoma, ovarian, } \\
\text { lung and colorectal cancers }\end{array}$ \\
- Synthetic derivatives: topotecan and irinotecan & (bark and stem) & \\
\hline $\begin{array}{l}\text { Vinca alkaloids (vincristine and vinblastine) } \\
\text { - Synthetic derivatives: vinorelbine, vindesine, and } \\
\text { vinovelbine }\end{array}$ & $\begin{array}{l}\text { Catharanthus roseus (leaves } \\
\text { and bark) }\end{array}$ & $\begin{array}{l}\text { Microtubules acting agent that arrests cell cycle in leuke- } \\
\text { mia, breast, lung and liver cancers }\end{array}$ \\
\hline
\end{tabular}




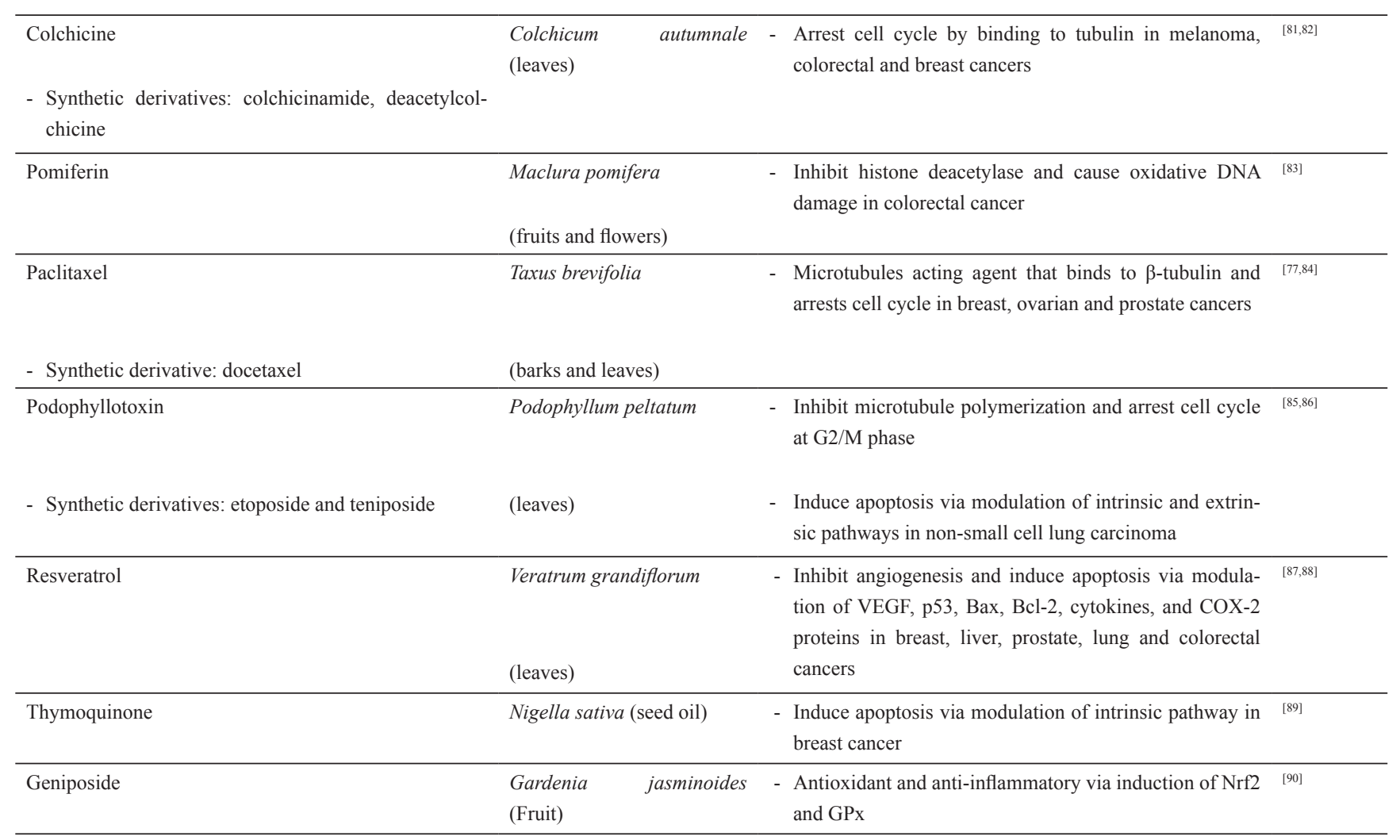

\section{NANOTECHNOLOGY IN DRUG DELIVERY: NANOMEDICINE}

The word "Nano" comes from the Greek "nannos" (dwarf or a very short man) that refers to the prefix of one-billionth of a meter (a factor of $\left.10^{-9}\right)^{[91]}$. According to the National Nanotechnology Initiative (NNI), nanotechnology is defined as "the knowledge and manipulation of matter within nanometer scale (1-100 $\mathrm{nm}$ ) that comprises multidisciplinary fields of nanoscale science, engineering and technology". Owing to the abilities to shape, process and create things at nanoscale, nanotechnology has been addressed as the next "Industrial Revolution" that offers tremendous advances to human being in the application of communications, chemistry, engineering, medicine and robotics ${ }^{[91,92]}$.

One of the most active applications of nanotechnology is nanomedicine ${ }^{[93]}$. Nanomedicine is defined as "the application of nanotechnology in the field of medicine"[94] With the utilisation of nanoparticles, nanotechnology has brought positive impact to human health in diagnosis, prevention and treatment of diseases ${ }^{[95]}$. It involves the development of nanomaterials and nanodevices for the applications of drug delivery, in vivo diagnosis, implants and nanotheranostics ${ }^{[96]}$. Nowadays, various types of material have emerged as useful nanomaterials for the development of drug delivery system. The nanoparticles can take various shapes and sizes with distinct properties depending on the types of nanomaterials used. Generally, nanoparticle-based drug delivery systems can be categorized based on biological-origin materials (such as phospholipids, dextran, lipids, chitosan, and lactic acid) or inorganic materials (such as polymers, carbon, silica and metals $)^{[97,98]}$. The family of nanoparticles, including polymeric nanoparticles, lipid nanoparticles and inorganic nanoparticles, is illustrated in Figure $3^{[99]}$.

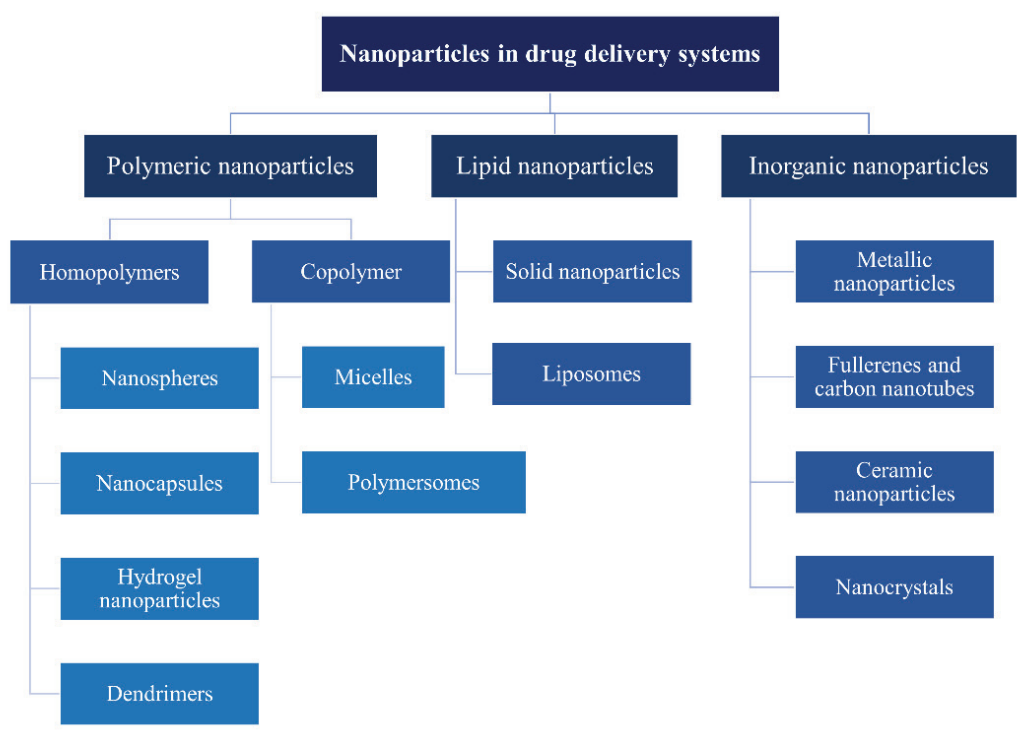

Figure 3. Family of nanoparticles in drug delivery systems. 
Drug delivery is defined as "a process of delivering a pharmaceutical agent for pharmacological reactions" $[100]$. An ideal drug carrier used in the drug delivery system should possess the ability to transport the optimum dose of pharmaceutical agent to the desired site without causing adverse side effects in other tissues due to unwanted accumulation ${ }^{[101]}$. Besides, the intentions of drug carriers are to protect the therapeutic agents from degradation by gastrointestinal enzymes, to improve the bioavailability of hydrophobic or lipophilic therapeutic agents and to facilitate controlled release of drug ${ }^{[102-106]}$.On top of these criteria, nanoparticles have been developed as the novel drug delivery system that provide extra advantages of low possibility of rapid clearance from the body through extravasation or prevention from phagocytosis by macrophage due to their nanometer size $^{[107,108]}$.

\section{Limitations of Conventional Delivery of Che- motherapeutic Agents}

Chemotherapy is the most common therapeutic approach for breast cancer. The highly-cytotoxic chemotherapeutic agents are directly administered into the blood circulating system by intravenous or oral route to kill rapidly-dividing cells ${ }^{[110]}$. However, this conventional drug delivery system encounters some drawbacks as follows:

A Non-specificity of chemotherapeutic agents: The random distribution and non-specific targeting of chemotherapeutic agents in the body system have caused unwanted accumulation and toxicity to other normal cells that divide rapidly such as bone marrow, hair follicle and digestive tract cells ${ }^{[111]}$. The most common adverse effects of chemotherapy are anaemia, alopecia, nausea, vomiting and acute cholinergic gastrointestinal effects $^{[112]}$.

B Poor pharmacokinetics via oral administration: Cancer is considered as chronic disease that requires long term frequent treatment. Therefore, oral route of drug administration has been the most preferred choice due to the reasons of patient's convenience, compliance, lower cost and painless ${ }^{[113]}$. Nevertheless, the desired therapeutic dose needed for maximum therapeutic effect is hard to achieve via oral administration of active drugs due to the enzymatic and hydrolytic degradation in the gastro-intestinal fluids, low cell uptake in the gastro-intestinal tract, firstpass hepatic metabolism, susceptibility to efflux transport and short biological half-life ${ }^{[114,115]}$.

C Poor aqueous solubility: Conventional delivery of chemotherapeutic agents remains a challenge as more than $40 \%$ of the potential anti-cancer compounds are hydrophobic or lipophilic. The insolubility of these drugs in water becomes an issue as they could not achieve the desired concentration in the systemic circulation. Therefore, various methods have been applied to improve the drug solubility such as drug carrier, chemical/physical modification of drugs, use of surfactant and salt formation ${ }^{[14]}$.

\section{APPLICATION OF NOVEL DRUG DELIVERY} SYSTEM IN CANCER THERAPY

Nanotechnology has appeared as an attractive approach for solving the drawbacks of conventional drug delivery system of chemotherapy. In principle, the potential or existing chemotherapeutic agents are conjugated or encapsulated in the nanoparticles in order to improve their pharmacokinetics and bioavailability ${ }^{[16,117]}$. As compared to discovery of new chemotherapeutic agents, the development of this novel drug delivery system only utilized half of the time (6-8 years) and $20 \%$ of the cost ( $\$ 50-\$ 60$ million) to be clinically approved and marketed ${ }^{[111]}$.

In 2005, the National Cancer Institute (NCI) has launched the Alliance for Nanotechnology in Cancer due to the emerging of nanomedicine and their potential applications in cancer research. Under this approach, nanoparticle-based drug delivery system has been approved as one of the promising strategies to overcome the limitations of conventional chemotherapy with numerous nanoparticle-based drugs and delivery system that are in clinical use.

An effective chemotherapeutic drug delivery to a solid tumour involves five steps which are circulation in blood, accumulation and penetration in the tumour, internalization by cancerous cell and drug release (CAPIR) ${ }^{[118]}$ (Figure 4).

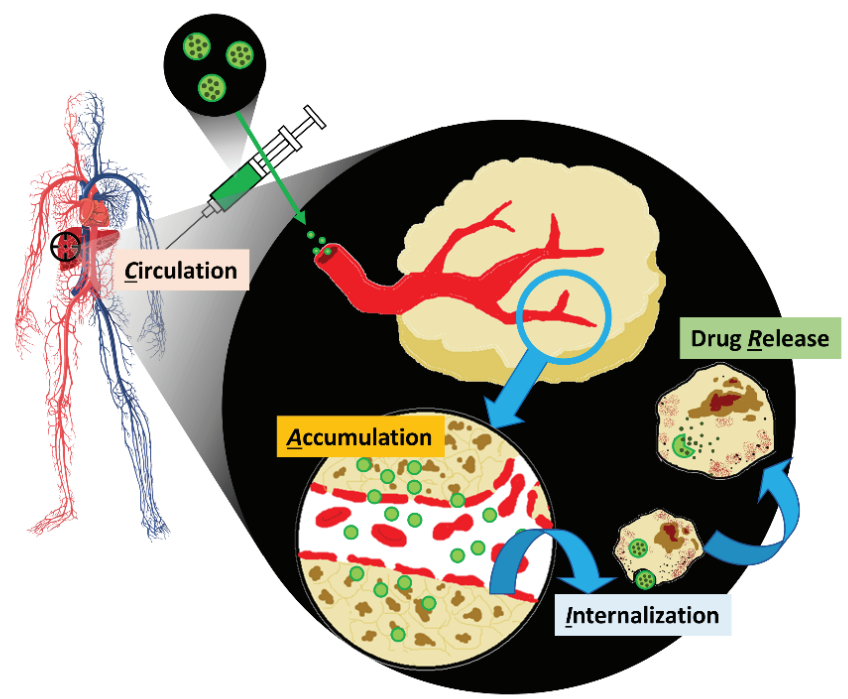

Figure 4. The CAPIR cascade of chemotherapeutic drug delivery ${ }^{[18]}$.

The overall therapeutic efficiency of chemotherapeutic drugs is improved by nanoparticle-based drug delivery system by its abilities of accumulation and penetration in tumour, which could be achieved by either passive or active targeting (Figure 5) ${ }^{[119]}$.
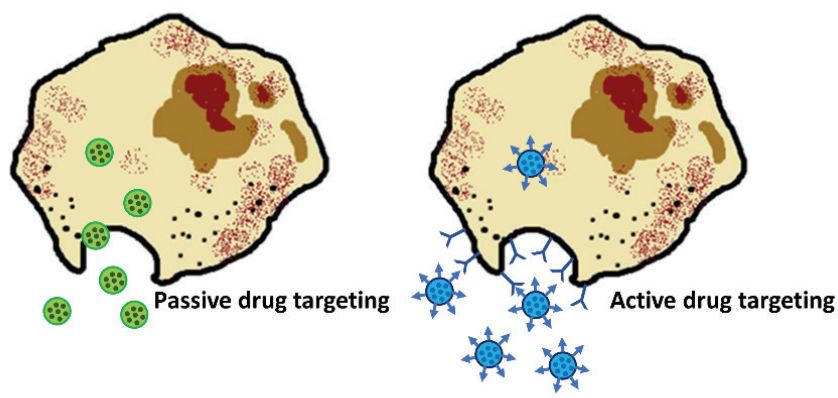

Figure 5. Targeted delivery system by nanoparticles ${ }^{[15]}$. 
In passive targeting, the circulating nanoparticles could passively extravasate from blood vessels and accumulate in the tumour via enhanced permeability and retention (EPR) effect. This EPR effect could only be achieved in tumour due to its unique characteristics of leaky blood vasculature and poor lymphatic drainage ${ }^{[120]}$. The normal blood vessels are endowed with tight junctions that could allow molecules less than $10 \mathrm{~nm}$ to permeate; meanwhile, the fast growing blood vessels that surround the tumour are highly disorganized and dilated due to the defective smooth muscle and enlarged gap junctions, allowing molecules less than $600 \mathrm{~nm}$ to permeate $^{[121,122]}$. Furthermore, the tumour possesses poor lymphatic system that further enhances the entrapment of nanoparticles in the tumour ${ }^{[123]}$.

On the other hand, active targeting can be achieved by attaching the ligands (proteins or antibodies) on the surface of nanoparticles that can interact with specific over-expressed receptors on the tumour ${ }^{[123,124]}$. In principle, this mechanism allows the nanoparticles to identify and recognise cancerous cells, thus minimising the unwanted systemic exposure of chemotherapeutics to other tissue $^{[123]}$. Table 2 shows some examples of clinically approved nanomedicine for cancer chemotherapy ${ }^{[109,125]}$.

\section{CONCLUSION}

Natural products have been showing impressive potentials as chemotherapeutic agents for cancer treatment, but their success in clinical trial has been limited as they have low solubility and bioavailability. The era of nanomedicine in cancer therapeutics has promisingly overcome the challenges hampering conventional therapy regimes hurdled by barriers of low solubility and physiological stability, poor bioavailability and specificity and high toxicity. Nanotechnology has revolutionized current cancer therapeutic modalities with the introduction of nano-drug delivery systems which are more efficient and less toxic as well as enhanced specificity to target tumor cells. The present in vitro and in vivo results pose a promising picture, but much more efforts are required from basic molecular aspects to preclinical and clinical trials before advancing more clinical use of nanoformulations in cancer chemotherapy.

Table 2. Clinically approved nanomedicine for cancer treatment ${ }^{[109,125]}$.

\begin{tabular}{|c|c|c|c|c|}
\hline Nanoparticle & Trade name & Description & Type of cancer & Manufacturer \\
\hline \multirow[t]{6}{*}{ Liposome } & Doxil $\mathbb{}$ & $\begin{array}{l}\text { - Doxorubicin encapsulated in PEGylated } \\
\text { liposomes } \\
\text { - } \quad \text { Reduced toxicity of doxorubicin }\end{array}$ & Ovarian and breast cancer & Orthobiotech, Schering-Plough \\
\hline & Myocet $\AA$ & $\begin{array}{l}\text { - Doxorubicin citrate encapsulated in liposomes } \\
\text { - Lower clearance and higher half life of drug }\end{array}$ & Breast cancer & Elan/Sopherion therapeutics \\
\hline & Marqibo® & $\begin{array}{l}\text { - Vincristine sulfate encapsulated in liposomes } \\
\text { - Lower clearance }\end{array}$ & Acute lymphoblastic leukemia & Talon Therapeutics, Inc. \\
\hline & $\begin{array}{l}\text { Dau- } \\
\text { noXome }{ }^{\circledR}\end{array}$ & $\begin{array}{l}\text { - Doxorubicin encapsulated in non-PEGylated } \\
\text { liposomes } \\
\text { - Prolonged circulation time and higher ac- } \\
\text { cumulation in tumour site }\end{array}$ & $\begin{array}{l}\text { HIV-associated Kaposi’s } \\
\text { sarcoma }\end{array}$ & Galen Pharmaceutics \\
\hline & Marqibo ${ }^{\circledR}$ & $\begin{array}{l}\text { - Vincristine encapsulated in non-PEGylated } \\
\text { liposomes } \\
\text { - Reduced toxicity and higher accumulation in } \\
\text { tumour site }\end{array}$ & $\begin{array}{l}\text { Philadelphia chromosome- } \\
\text { negative acute lymphoblastic } \\
\text { leukemia }\end{array}$ & Spectrum Pharmaceuticals \\
\hline & Onivyde ${ }^{\circledR}$ & $\begin{array}{l}\text { - Irinotecan encapsulated in non-PEGylated } \\
\text { liposomes } \\
\text { - Prolonged circulation time, and higher ac- } \\
\text { cumulation in tumour site }\end{array}$ & Pancreatic cancer & Merrimack Pharmaceutics \\
\hline \multirow[t]{3}{*}{$\begin{array}{l}\text { Polymer- } \\
\text { based } \\
\text { nanoparticle }\end{array}$} & Genexol® & - Paclitaxel in PEG-PLA copolymer micelles & $\begin{array}{l}\text { Metastatic breast cancer and } \\
\text { pancreatic cancer }\end{array}$ & Samyang Biopharmaceuticals \\
\hline & Opaxio ${ }^{\circledR}$ & $\begin{array}{l}\text { - Soluble ester conjugate of paclitaxel and } \\
\text { a-poly(L)-glutamic acid } \\
\text { - } \quad \text { Prolonged tumour exposure of paclitaxel } \\
\text { - } \quad \text { Reduced neutropenia and alopecia }\end{array}$ & Ovarian cancer & Cell therapeutics \\
\hline & Eligard $®$ & $\begin{array}{l}\text { - Lueprolide acetate and polymer } \\
\text { - Prolonged drug circulation time and con- } \\
\text { trolled drug release }\end{array}$ & Prostate cancer & Tolmar Pharmaceutics \\
\hline
\end{tabular}




\begin{tabular}{|c|c|c|c|c|}
\hline \multirow[t]{2}{*}{$\begin{array}{l}\text { Protein-drug } \\
\text { conjugates }\end{array}$} & Abraxane $\AA$ & $\begin{array}{l}\text { - Paclitaxel conjugated with albumin } \\
\text { - Enhanced endothelial transcytosis via } \\
\text { albumin-receptor mediated pathway }\end{array}$ & $\begin{array}{l}\text { Breast cancer and non-small } \\
\text { cell lung cancer }\end{array}$ & Abraxis Bioscience, Astra Zenica \\
\hline & Ontak ${ }^{\circledR}$ & $\begin{array}{ll}\text { - } & \text { Denileukin diftitox } \\
\text { - } & \text { Specifically targeted to T-cell }\end{array}$ & Cutaneous T-cell lymphoma & Eisai \\
\hline $\begin{array}{l}\text { Metal } \\
\text { nanoparticle }\end{array}$ & $\begin{array}{l}\text { Nano- } \\
\text { Therm }{ }^{\circledR}\end{array}$ & $\begin{array}{l}\text { - Aminosilane-coated with superparamagnetic } \\
\text { iron oxide } \\
\text { - Thermal ablation by generating heat directly } \\
\text { within the tumour tissue }\end{array}$ & $\begin{array}{l}\text { Glioblastoma and prostate } \\
\text { cancer }\end{array}$ & MagForce AG \\
\hline
\end{tabular}

Abbreviation: PEG-PLA, poly(ethylene glycol)-poly(D,L-lactide).

\section{Author Contributions}

Y-SO, LT-HT participated in the writing of the manuscript. Y-SO conceptualized the project.

\section{Conflict of interest}

The authors hereby declare no competing interest.

\section{Acknowledgements}

This work was financially supported by Monash Global Asia in the 21st Century (GA21) research grant (GA-HW-19-L01 \& GA-HW-19-S01).

\section{Reference}

1. Bray F, Ferlay J, Soerjomataram I, et al. Global cancer statistics 2018: GLOBOCAN estimates of incidence and mortality worldwide for 36 cancers in 185 countries. CA Cancer J Clin 2018; 68(6): 394-424

2. Tan LT-H, Chan K-G, Khan TM, et al. Streptomyces sp. MUM212 as a source of antioxidants with radical scavenging and metal chelating properties. FRONT Pharmacol 2017; 8 : 276.

3. Baker DD, Chu M, Oza U, et al. The value of natural products to future pharmaceutical discovery. Nat. Prod. Rep. 2007; 24(6) $1225-1244$.

4. Tan LT-H, Chan K-G, Chan CK, et al. Antioxidative potential of a Streptomyces sp. MUM292 isolated from mangrove soil. Biomed Res. Int. 2018; 2018.

5. Tan LT-H, Chan K-G, Pusparajah P, et al., Mangrove derived Streptomyces sp. MUM265 as a potential source of antioxidan and anticolon-cancer agents. BMC Microbiol 2019; 19(1): 38.

6. Tan LT-H, Ser H-L, Yin W-F, et al. Investigation of antioxidative and anticancer potentials of Streptomyces sp. MUM256 isolated from Malaysia mangrove soil. Front Microbiol 2015; 6: 1316.

7. Kemung HM, Tan LT-H, Khan TM, et al. Streptomyces as a prominent resource of future anti-MRSA drugs. Front Microbiol 2018; 9: 2221.

8. Ser H-L, Tan LT-H, Law JW-F, et al. Focused review: cytotoxic and antioxidant potentials of mangrove-derived Streptomyces Front Microbiol 2017; 8: 2065

9. Tan LT-H, Lee L-H, and Goh B-H. The bioprospecting of antiVibrio Streptomyces species: prevalence and applications. Prog Microbes Mol Biol 2019; 2(1).

10. Kemung HM, Tan LT-H, Chan K-G, et al. Antioxidant activities of Streptomyces sp. strain MUSC 14 from mangrove forest soil in Malaysia. Biomed Res. Int. 2020; 2020.

11. Tan LT-H, Chan C-K, Chan K-G, et al. Streptomyces sp. MUM256: A source for apoptosis inducing and cell cyclearresting bioactive compounds against colon cancer cells. J. Cancer 2019; 11(11): 1742

12. Lee L-H, Chan K-G, Stach J, et al. The search for biological active agent (s) from actinobacteria. Front Microbiol 2018; 9: 824.

13. Ma DS, Tan LT-H, Chan K-G, et al. Resveratrol-potentia antibacterial agent against foodborne pathogens. Front
Pharmacol 2018; 9: 102.

14. Savjani KT, Gajjar AK, and Savjani JK. Drug solubility: importance and enhancement techniques. ISRN Pharm 2012; 2012: $10-10$

15. Sanna V, Pala N, and Sechi M. Targeted therapy using nanotechnology: focus on cancer. Int J Nanomedicine 2014; 9: 467-483.

16. National Cancer Institute. NCI Dictionary of Cancer Terms National Cancer Institute of Health; 2017.

17. Hanahan D and Weinberg RA. Hallmarks of cancer: the next generation. Cell J 2011; 144(5): 646-674.

18. Eng S-K, Tan LT-H, Goh B-H, et al. KRAS as potential target in colorectal cancer therapy, in Natural Bio-active Compounds: Volume 1: Production and Applications, M.S. Akhtar, M.K. Swamy, and U.R. Sinniah, Editors. 2019, Springer Singapore: Singapore. 389-424.

19. Yusof AM, Tieng FYF, Muhammad R, et al. In-depth characterization of miRNome in papillary thyroid cancer with BRAF V600E mutation. Prog Microbes Mol Biol 2020; 3(1).

20. Chow YP, Yunos RIM, Rose IM, et al. Characterization of somatic mutations in Malaysian luminal breast cancer. Prog Microbes Mol Biol 2018; 1(1)

21. Lye KL, Tan LT-H, and Yap HM. Insight of microRNA role in colorectal cancer. Prog Microbes Mol Biol 2020 3(1): a0000083.

22. Ishak M, Baharudin R, Tan LTH, et al. Landscape of HOXA genes methylation in colorectal cancer. Prog Microbes Mol Biol 2020; 3(1): a0000085.

23. Jain M, Kasetty S, Khan S, et al., An insight to apoptosis. J Res Pract Dent 2014; 2014: 12-12.

24. Elmore S. Apoptosis: a review of programmed cell death. Toxicol Pathol 2007; 35(4): 495-516.

25. Ouyang L, Shi Z, Zhao S, et al., Programmed cell death pathways in cancer: A review of apoptosis, autophagy and programmed necrosis. Cell Proliferat 2012; 45(6): 487-498.

26. Adigun R and Bhimji SS. Necrosis, cell (liquefactive, coagulative, caseous, fat, fibrinoid, and gangrenous). StatPearls: 2007.

27. Berghe TV, Linkermann A, Jouan-Lanhouet S, et al. Regulated necrosis: the expanding network of non-apoptotic cell death pathways. Nat Rev Mol Cell Biol 2014; 15(2): 135-147.

28. Kerr JFR, Wyllie AH, and Currie AR. Apoptosis: a basic biological phenomenon with wide-ranging implications in tissue kinetics. Br J Cancer 1972; 26(4): 239-257.

29. Lockshin RA and Zakeri Z. Cell death in health and disease. J Cell Mol Med 2007; 11(6): 1214-1224

30. Verhoven B, Schlegel RA, and Williamson P. Mechanisms of phosphatidylserine exposure, a phagocyte recognition signal, on apoptotic T lymphocytes. J Exp Med 1995; 182(5): 1597-1601.

31. Inoue $\mathrm{H}$ and Tani $\mathrm{K}$. Multimodal immunogenic cancer cell death as a consequence of anticancer cytotoxic treatments. Cell Death Differ 2014; 21(1): 39-49.

32. Yunos R-IM, Ab Mutalib N-S, Khor SS, et al. Whole exome sequencing identifies genomic alterations in proximal and distal colorectal cancer. Prog Microbes Mol Biol 2019; 2(1).

33. Beckerman $\mathrm{R}$ and Prives $\mathrm{C}$. Transcriptional regulation by $\mathrm{p} 53$. Cold Spring Harb Perspect Biol 2010; 2(8): a000935-a000935.

34. Walerych D, Napoli M, Collavin L, et al. The rebel angel: mutant p53 as the driving oncogene in breast cancer. Carcinog 2012; 33(11): 2007-2017.

35. White J. Apoptosis: The intrinsic pathway, E.P. Gelmann, C.L. Sawyers, and F.J. Rauscher, Editors. 2014, Cambrige University Press: United States. p. 367-378.

36. Wei YY, Chen YJ, Hsiao YC, et al Osteoblasts-derived TGFbetal enhance motility and integrin upregulation through Akt, ERK, and NF-kappaB-dependent pathway in human breast cancer cells. Mol Carcinog 2008; 47(7): 526-537.

37. Khan KH, Blanco-Codesido $\mathrm{M}$, and Molife LR Cancer therapeutics: targeting the apoptotic pathway. Crit Rev Oncol Hemat 2014; 90(3): 200-219.

38. McLlwain DR, Berger T, and Mak TW. Caspase functions in cell death and disease. Cold Spring Harb Perspect Biol 2013; 5(4): $1-28$.

39. Folkman J. Tumor angiogenesis: therapeutic implications. N Engl J Med 1971; 285(21): 1182-1186. 
40. Bielenberg DR and Zetter BR. The contribution of angiogenesis to the process of metastasis. Cancer J 2015; 21(4): 267-273.

41. Folkman J. Looking for a good endothelial address. Cancer Cell 2002; 1(2): 113-115.

42. Dimova I, Popivanov G, and Djonov V. Angiogenesis in cancer general pathways and their therapeutic implications. J BUON 2014; 19(1): 15-21.

43. Zhao Y and Adjei AA. Targeting angiogenesis in cancer therapy: moving beyond vascular endothelial growth factor. Oncologist 2015; 20(6): 660-673.

44. Yilmaz M, Christofori G, and Lehembre F. Distinct mechanisms of tumor invasion and metastasis. Trends Mol Med 2007; 13(12): 535-541.

45. Ferlay J, Soerjomataram I, Dikshit R, et al. Cancer incidence and mortality worldwide: sources, methods and major patterns in GLOBOCAN 2012. Int J Cancer 2015; 136(5): 359-386.

46. Bogenrieder T and Herlyn M. Axis of evil: molecular mechanisms of cancer metastasis. Oncogene 2003; 22(42): 6524-6536.

47. Chang $\mathrm{C}$ and Werb Z. The many faces of metalloproteases: cell growth, invasion, angiogenesis and metastasis. Trends Cell Biol. 2001; 11(11): 37-43

48. Tan LT-H, Chan K-G, Lee L-H, et al. Streptomyces bacteria as potential probiotics in aquaculture. Front Microbiol 2016; 7: 79.

49. Ser H-L, Tan LT-H, Palanisamy UD, et al. Streptomyces antioxidans sp. nov., a novel mangrove soil actinobacterium with antioxidative and neuroprotective potentials. Front Microbiol 2016; 7: 899.

50. Tan LT-H, Mahendra CK, Yow YY, et al. Streptomyces sp. MUM273b: A mangrove $\square$ derived potential source for antioxidant and UVB radiation protectants. Microbiologyopen 2019; 8(10): e859.

51. Chee PY, Mang M, Hern T, et al. Epinecidin-1, an antimicrobial peptide derived from grouper (Epinephelus coioides): Pharmacological activities and applications. Front Microbiol 2019; 10: 2631 .

52. Law JW-F, Letchumanan V, Tan LT-H, et al. The rising of "Modern Actinobacteria" era. Prog Microbes Mol Biol 2020; 3(1).

53. Kemung HM, Tan LT-H, Chan K-G, et al. Investigating the antioxidant potential of Streptomyces sp. MUSC 11 from mangrove soil in Malaysia. Prog Drug Discovery \& Biomed Sci 2019; 2(1).

54. Tan LT-H, Lee L-H, and Goh B-H. Critical review of fermentation and extraction of anti-Vibrio compounds from Streptomyces. Prog Microbes Mol Biol 2020; 3(1)

55. Law JW-F, Ser H-L, Duangjai A, et al. Streptomyces colonosanans sp. nov., a novel actinobacterium isolated from Malaysia mangrove soil exhibiting antioxidative activity and cytotoxic potential agains human colon cancer cell lines. Front Microbiol 2017; 8: 877.

56. Azman A-S, Othman I, Fang C-M, et al. Antibacterial, anticancer and neuroprotective activities of rare Actinobacteria from mangrove forest soils. Indian J Microbiol 2017; 57(2): 177-187.

57. Ser H-L, Yin W-F, Chan K-G, et al. Antioxidant and cytotoxic potentials of Streptomyces gilvigriseus MUSC 26T isolated from mangrove soil in Malaysia. Prog Microbes Mol Biol 2018; 1(1).

58. Law JW-F, Tan K-X, Wong SH, et al. Taxonomic and characterization methods of Streptomyces: a review. Prog Microbes Mol Biol 2018; $1(1)$.

59. Ser H-L, Chan K-G, Tan W-S, et al. Complete genome of mangrovederived anti-MRSA streptomycete, Streptomyces pluripotens MUSC 135T. Prog Microbes Mol Biol 2018; 1(1).

60. Ser H-L, Ab Mutalib N-S, Yin W-F, et al. Genome sequence of Streptomyces antioxidans MUSC 164T isolated from mangrove forest. Prog Microbes Mol Biol 2018; 1(1).

61. Law JW-F, Pusparajah P, Ab Mutalib N-S, et al. A review on mangrove actinobacterial diversity: The roles of streptomyces and novel species discovery. Prog Microbes Mol Biol 2019; 2(1).

62. Ong K-S, Letchumanan V, Law JW-F, et al. Microbes from peat swamp forest - the hidden reservoir for secondary metabolites? Prog Microbes Mol Biol 2020; 3(1).

63. Cragg GM and Newman DJ, Natural product drug discovery in the next millennium. Pharm Biol 2001; 39: 8-17.

64. Chan C-K, Tan LT-H, Andy SN, et al. Anti-neuroinflammatory activity of Elephantopus scaber L. via activation of Nrf2/HO-1 signaling and inhibition of p38 MAPK pathway in LPS-induced microglia BV-2 cells. Front pharmacol 2017; 8: 397.

65. Chan W-K, Tan LT-H, Chan K-G, et al. Nerolidol: a sesquiterpene alcohol with multi-faceted pharmacological and biological activities. Molecules 2016; 21(5): 529

66. Tan LT-H, Lee LH, Yin WF, et al. Traditional uses, phytochemistry, and bioactivities of Cananga odorata (Ylang-Ylang). Evid Based Complement Alternat Med 2015; 2015.

67. Tang C, Hoo PC-X, Tan LT-H, et al. Golden needle mushroom: a culinary medicine with evidenced-based biological activities and health promoting properties. Front Pharmacol 2016; 7: 474.

68. Tay K-C, Tan LT-H, Chan CK, et al. Formononetin: A review of its anticancer potentials and mechanisms. Front Pharmacol 2019; 10.

69. Goh JXH, Tan LT-H, Goh JK, et al. Nobiletin and derivatives: Functional compounds from citrus fruit peel for colon cancer chemoprevention. Cancers 2019; 11(6): 867.

70. Tan LT-H, Low LE, Tang SY, et al., A reliable and affordable 3D tumor spheroid model for natural product drug discovery: A case study of curcumin. Prog Drug Discovery \& Biomed Sci 2019; 2(1).

71. Tan LT-H, Khaw KY, Ong YS, et al. An overview of Clinacanthus nutans (Burm. f.) Lindau as a medicinal plant with diverse pharmacological values, in Plant-derived Bioactives. Springer 2020

72. Mahendra CK, Tan LTH, Lee WL, et al. Angelicin - a furocoumarin compound with vast biological potential. Front Pharmacol 2020; 11

73. Tan H-L, Chan K-G, Pusparajah P, et al. Anti-cancer properties of the naturally occurring aphrodisiacs: icariin and its derivatives. Front Pharmacol 2016; 7: 191.

74. Chan CK, Tang LY, Goh BH, et al., Targeting apoptosis via inactivation of PI3K/Akt/mTOR signaling pathway involving NF- $\mathrm{\kappa B}$ by geraniin in HT-29 human colorectal adenocarcinoma cells. Prog Drug Discovery \& Biomed Sci 2019; 2(1).

75. Khaw KY, Ong YS, and Goh B-H. A Rapid Method for the Retrieval of Bioactive Xanthone from Garcinia Mangostana: A Case Study of $\alpha$-Mangostin. Prog Drug Discovery \& Biomed Sci 2020; 3(1): a0000072.

76. Kuppusamy P, Yusoff MM, Maniam GP, et al. A case study - regulation and functional mechanisms of cancer cells and control its activity using plants and their derivatives. J Pharm Res 2013; 6(8): 884-892.

77. Wani MC, Taylor HL, Wall ME, et al. Plant antitumor agents. VI. The isolation and structure of taxol, a novel antileukemic and antitumor agent from Taxus brevifolia. J Am Chem Soc 1971; 93(9): 2325-2327.

78. Wall ME, Wani MC, Cook CE, et al. Plant antitumor agents. I. The isolation and structure of camptothecin, a novel alkaloidal leukemia and tumor inhibitor from Camptotheca acuminata. J Am Chem Soc 1966; 88(16): 3888-3890.

79. Johnson IS, Armstrong JG, Gorman M, et al. The Vinca alkaloids: A new class of oncolytic agents. Cancer Res 1963; 23: 1390-1427.

80. Moudi M, Go R, Yien CYS, et al. Vinca alkaloids. Int J Prev Med 2013; 4(11): 1231-1235.

81. Ford CE and Hamerton JL. A colchicine, hypotonic citrate, squash sequence for mammalian chromosomes. Biotech Histochem 1956; 31(6): 247-251

82. Ade R and Rai MK. Review: Colchicine, current advances and future prospects. Nusantara Biosci 2010; 2(2): 90-96.

83. Son IH, Chung IM, Lee SI, et al. Pomiferin, histone deacetylase inhibitor isolated from the fruits of Maclura pomifera. Bioorg Med Chem Lett 2007; 17(17): 4753-4755.

84. Khanna C, Rosenberg M, and Vail DM. A review of paclitaxel and novel formulations including those suitable for use in dogs. J Vet Intern Med 2015; 29(4): 1006-1012.

85. Choi JY, Hong WG, Cho JH, et al. Podophyllotoxin acetate triggers anticancer effects against non-small cell lung cancer cells by promoting cell death via cell cycle arrest, ER stress and autophagy. Int J Onco 2015; 47(7): 1257-1265.

86. Podwissotzky V. Pharmakologische studien uber Podophyllum peltatum. Arch Exp Pathol Pharmakol 1881; 13: 29-53.

87. Varoni EM, Lo Faro AF, Sharifi-Rad J, et al. Anticancer molecular mechanisms of resveratrol. Front Nutr 2016; 3: 8-8.

88. Takaoka M. Resveratrol, a new phenolic compound, from Veratrum grandiflorum. J Chem Soc Jpn 1939; 60(1): 1090-1100.

89. Ong YS, Yazan LS, Ng WK, et al. Thymoquinone loaded in nanostructured lipid carrier showed enhanced anticancer activity in 4T1 tumor-bearing mice. Nanomed 2018; 13(13): 1567-1582.

90. Habtemariam S and Lentini G. Plant-Derived Anticancer Agents: Lessons from the Pharmacology of Geniposide and Its Aglycone, Genipin. Biomed 2018; 6(2).

91. Allhoff F. The coming era of nanomedicine. Am J Bioeth 2009; 9(10): 3-11.

92. Safari $\mathrm{J}$ and Zarnegar Z. Advanced drug delivery systems: Nanotechnology of health design, a review. J Saudi Chem Soc 2014; 18(2): 85-99.

93. James K, Highsmith J, and Evers P. Nanotechnology market nanotechnology markets in healthcare and medicine. 2014

94. European Science Foundation. European Medical Research Councils (EMRC) forward look report. 2005. p. 1-47.

95. Astruc D. Introduction to nanomedicine. Mol 2015; 21(1): 6-6.

96. Singh S and Singh A. Current status of nanomedicine and nanosurgery. Anesth Essays Res 2013; 7(2): 237-242.

97. Low LE, Tan LT-H, Goh B-H, et al. Magnetic cellulose nanocrystal stabilized Pickering emulsions for enhanced bioactive release and human colon cancer therapy. Int J Biol Macromol 2019; 127: 76-84.

98. Wu Y-S, Ngai S-C, Goh B-H, et al. Anticancer activities of surfactin and potential application of nanotechnology assisted surfactin delivery. Front Pharmacol 2017; 8: 761

99. Kumar A, M. Mansour H, Friedman A, et al. Nanomedicine in drug deliv. CRC Press: 2013. 469 p.

100. Tiwari G, Tiwari R, Sriwastawa B, et al. Drug delivery systems: an updated review. Int J Pharm Investig 2012; 2(1): 2-11.

101. Tran PA, Zhang L, and Webster TJ. Carbon nanofibers and carbon nanotubes in regenerative medicine. Adv Drug Deliv Rev 2009; 61(12): 1097-1114.

102. Luan J, Zhang D, Hao L, et al. Design and characterization of Amoitone B-loaded nanostructured lipid carriers for controlled drug release. Drug Deliv 2013; 20(8): 324-330.

103. Pardeike J, Weber S, Matsko N, et al. Formation of a physical stable delivery system by simply autoclaving nanostructured lipid carriers (NLC). Int J Pharm 2012; 439(1-2): 22-27.

104. Müller RH, Radtke M, and Wissing SA. Nanostructured lipid matrices for improved microencapsulation of drugs. Int J Pharm 2002; 242(1 2): $121-128$.

105. Yew H-C and Misran M, Characterization of fatty acid based nanostructured lipid carrier (NLC) and their sustained release properties. Prog Drug Discovery \& Biomed Sci 2019; 2(1).

106. Ong YS, Saiful Yazan L, Ng WK, et al. Acute and subacute toxicity profiles of thymoquinone-loaded nanostructured lipid carrier in $\mathrm{BALB} / \mathrm{c}$ mice. Int J Nanomed 2016; 11: 5905-5915.

107. Vinogradov SV, Bronich TK, and Kabanov AV. Nanosized cationic hydrogels for drug delivery: preparation, properties and interactions 
with cells. Adv Drug Deliv Rev 2002; 54(1): 135-147.

108. Stolnik S, Illum L, and Davis SS. Long circulating microparticulate drug carriers. Adv Drug Deliv Rev 1995; 16(2-3): 195-214

109. Weissig V, Pettinger TK, and Murdock N. Nanopharmaceuticals (part 1): products on the market. Int J Nanomed 2014; 9: 43574373.

110. Kakde D, Jain D, Shrivastava V, et al. Cancer therapeuticsopportunities, challenges and advances in drug delivery. J Appl Pharm Sci 2011; 1(9): 1-10.

111. Utreja P, Jain S, and Tiwary AK. Novel drug delivery systems for sustained and targeted delivery of anti-cancer drugs: current status and future prospects. Curr Drug Deliv 2010; 7(2): 152161.

112. Caley A and Jones R. The principles of cancer treatment by chemotherapy. Surgery (Oxford) 2012; 30(4): 186-190.

113. Zhang C, Newsome JT, Mewani R, et al. Systemic delivery and pre-clinical evaluation of nanoparticles containing antisense oligonucleotides and siRNAs. Methods Mol Biol 2009; 480: 65-83.

114. Mukherjee B, Satapathy BS, Bhattacharya S, et al. Pharmacokinetic and pharmacodynamic modulations of therapeutically active constituents from orally administered nanocarriers along with a glimpse of their advantages an limitations. In Grumezescu AM, editor. Encapsulation of Active Molecules and Their Delivery System. Elsevier; 2017. p. 357 375 .

115. DeMario MD and Ratain MJ. Oral chemotherapy: rationale and future directions. J Clin Oncol 1998; 16(7): 2557-2567.
116. Bobo D, Robinson KJ, Islam J, et al. Nanoparticle-based medicines: a review of FDA-approved materials and clinical trials to date. Pharm Res 2016; 33(10): 2373-2387.

17. Low LE, Ong BH, Tey BT, et al. Factors affecting the stability and physical properties of pickering emulsions stabilized by Fe3 O4@ CNC nanocomposites. Prog Drug Discovery \& Biomed Sci 2020; 3(1).

118. Sun Q, Sun X, Ma X, et al.. Integration of nanoassembly functions for an effective delivery cascade for cancer drugs. Adv. Mater 2014; 26(45): 7615-7621.

119. Din FU, Aman W, Ullah I, et al. Effective use of nanocarriers as drug delivery systems for the treatment of selected tumors. Int. J. Nanomed 2017; 2017(12): 7291-7309.

120. Maeda $\mathrm{H}, \mathrm{Wu}$ J, Sawa $\mathrm{T}$, et al. Tumor vascular permeability and the EPR effect in macromolecular therapeutics: a review. J Control Release 2000; 65(1-2): 271-284

121. Iyer AK, Khaled G, Fang J, et al. Exploiting the enhanced permeability and retention effect for tumor targeting. Drug Discov Today 2006; 11(17-18): 812-818.

122. Cho K, Wang X, Nie S, et al. Therapeutic nanoparticles for drug delivery in cancer. Clin. Cancer Res 2008; 14(5): 1310-1316.

123. Bazak R, Houri M, El Achy S, et al. Cancer active targeting by nanoparticles: a comprehensive review of literature. J Cancer Res Clin Oncol 2014; 141(5): 769-784.

124. Tan LT-H, Chan K-G, Pusparajah P, et al. Targeting membrane lipid a potential cancer cure? Front Pharmacol 2017; 8: 12.

125. Ragelle H, Danhier F, Préat V, et al. Nanoparticle-based drug delivery systems: a commercial and regulatory outlook as the field matures. Expert Opin Drug Deliv 2017; 14(7): 851-864. 